\title{
Exploring Identifications in the Transnational Social Sphere: The Potential of Social Fields
}

\section{Tea Golob}

\author{
Doctoral fellow, teaching assistant, School of Advanced Social Studies, \\ Nova Gorica, Slovenia \\ e-mail: tea.golob@fuds.si
}

\begin{abstract}
The article attempts to discuss certain issues related to contemporary identifications, social changes and technological development that are reflected in the transnational sphere. The first one refers to the possibility of individual action within social settings and therefore the extent of individual freedom from exterior influences is at the forefront. The second one tackles the individual or collective perception of selves and the exterior world, which then leads to the third question: how can one actually consider identity construction or identification in transnational social spheres? The notion we believe can elucidate the complex relationship between the individual and society and reveal important aspects in identity formations is that of the social field, particularly the transnational social field. In the modern era, individuals participate in many social fields which do not always correlate with local or national boundaries. The possibility of their individual freedom and social change is thus more present, but is still conditioned by different types of capital and other social forces. The concept evokes the idea of a habitus, which reflects a different context of a structured framework of evaluations and expectations which, as proposed by Bourdieu (1977), leads to the conscious or intuitive prioritising of certain dispositions and practices. The concept allows us to explore how socio-economic, cultural and personal backgrounds influence a person's identity negotiations and constructions in the transnational sphere, while it also encompasses the influence of border crossing and transnational connections.
\end{abstract}

Key words: identifications, social fields, transnational connections.

\section{Introduction}

Exploring identification processes is one of the most ambiguous scholarly tasks as there has been a flood of definitions referring to self-perceptions and group belongings. The concept is fluid, highly flexible and uncertain. Due to the excessive definitions of 'identity', the term has become widely contested. It has even been stated that "identity has become the watchword of the times" (Shotter, 1993:188, in Jacobs and Maier 1998:3), and many critics of the concept's credibility have emerged in recent decades (Bauman, 2000, Brubaker and Cooper, 2000). Nevertheless, it remains indisputable that processes of defining the self in relation to the outside environ- 
ment do exist. The sense of self-awareness, which gains its meaning in contextualising what is not being 'me', is an integral part of individual actions. The process of meaning-making is always processual and not a pre-given entity. Identities are more a project which is flexible and transferable to other people (Castells, 1997; Giddens, 1991).

Another important dimension of identity is their ambiguous and ambivalent nature. Identities are often hybrid, transversal and multi-layered, which has increasingly gained relevance in the recent era of global connectivity, accelerated movement and technological development. In accordance with global and transnational studies which have emerged as a response to the rapidly changing world, the concept of transnational, hybrid and creolised identities has come to the fore. Transnationality embraces the construction of identities which are not only limited by local and national boundaries, but are shaped within social spaces which extend beyond those frames. Transnational identities have become a popular concept especially in migration studies, yet the concept refers to any individuals and social groups that create their lives partly beyond national spheres. Every one of these individuals and groups, whether they are expatriates, entrepreneurs, international students etc., construct specific identities which should not be simplified by merely applying the common concept of the transnational.

Another issue that may be more important is that even within a single group the process of transnational identification is far from homogenous. Identifications take place on the basis of reflexive considerations of the individual's self-position in the social environment, but also simultaneously depend on particular predispositions shaped through ongoing interactions between traditions, worldviews and values of the individual's context of origin. The paper draws on the concept of social fields, which offers an understanding of identifications through interpretive frames of recent sociological theories that emphasise the dialectic relation between reflexivity and habitus (Adams, 2006). The main aim is to demonstrate the potential of the concept of social fields in its transnational variant and connect the argumentation to questions of transnational identity and processes of identification in the transnational sphere. The transnational social field concept is capable of shedding light on the dynamics of identity constructions which in the transnational sphere are more specific. Entry to a transnational social sphere is not a given fact for every individual, and adding a transnational layer to collective identities could be seen more as a privileged dimension of a few. A substantial role is played by the individual's ability to access to various types of capital: social, economic and cultural. The possession of different resources is essential as that opens the gate from local and national social fields to transnational ones. The transition between particular fields enables more intensive reflexivity and a consideration of an individual's action and also of the institutional frames in which they are embedded. Accordingly, transnational individuals have more social skills, which express what people do to attain collective action and give meaning and sense to our lives (cf. Fligstein and McAdam, 2012:46).

Transnational layers of identities can thus take on instrumental meanings and allow individuals to have greater control over their lives and more easily achieve their 
goals. Further, the concept of transnational social fields allows an understanding of the transnational context of the different dimensions of social fields relating to cognitive frames, institutional rules and relational topographies of networks (Beckert, 2010). It reveals how constant border crossing (physical or imaginary), transnational social interaction and institutions, and the life experiences of an individual from the past and other national or local environments make sense of the present and the self.

\section{Contemporary identifications, reflexivity and social dispositions}

Human society is becoming ever more complex and differentiated. The architecture of the social order has evolved from elementary forms to highly specialised and functionally differentiated social systems. New unpredictable and uncertain social areas have emerged which have influenced a number of transitions in everyday life as reflected in the character of social organisation and in the structuring of the global system (Beck, Giddens, Lash, 1994). The contemporary world situation reflects complex social phenomena linked to technological development, mass mediation and globalisation. The world we live in seems to be unstable, entailing that everything is always on the move. Social, economic and cultural connectivity has become quite an inevitable fact and the regular movement of people, goods and ideas have increasingly become part of the everyday reality.

Social transformations conditioned by global processes which connect different regions of the world through trade and labour exchange, such as international laws and organisations, and rapidly advancing transportation and communication technology have thus enabled new perspectives on social reality. Limitations of social time and geographical places, as key coordinates of modern social life, have ceased to present insurmountable obstacles to various forms of social interaction and organisation (Held and McGrew, 2003:3). The accelerating 'time-space compression', referring to the idea that both the logic of capitalist growth and the availability of technologies of instantaneous communication have radically transformed our perception of the world (Harvey, 1989), forms a condition for social change reflecting the dynamics between agents and social structure on different global and local levels. Social life has become constituted by the material world which reflects new distinguishing connections enabling and providing new mobilities, which involves the idea that structures are inextricably connected with processes (Urry, 2003). Individuals and their position in society have come to be seen in the light of ever-changing global conditions and transnational connections. Due to the global flows of ideas and goods, and the mass-culture of consumption that is accompanying changes in communication, people have become more exposed to diverse social and cultural differences (Adams, 2006; Rončević and Makarovič, 2012).

The influence of the rapid flow of mass-mediated images, scripts and sensations has brought about "a new order of instability in the production of modern subjectivities" (Appadurai, 1996:6), while networks of social relations, cultures of adaptation, and political and economic institutions also work on global and transnational levels. 
Expansive changes in communication technologies and structures have led to the relativisation of our established cultural and individual practice, while the multiplicity of ideas influences the perception of the self and identities (Gergen, 1991). One can say that, in general, traditional understandings of identities are no longer adequate in the era of global mass communications, mediation and migration, while the processes of globalisation have undermined the meaning of traditional conceptions of individuals as members of fixed and separate societies. It has been argued that identity formation should be conceived of in terms of fluidities of time and space (Rapport and Dawson, 1998), by taking account of the influence of simultaneous connections of people from different parts of the globe comprising various activities, ideas and identifications.

In recent decades, the notion of 'identity' has become a contested issue, widely criticised and deconstructed alongside many critiques that have accompanied the rejection of the self-sustaining subject placed at the centre of post-Cartesian Western metaphysics (Hall and Du Gay, 2000). The traditional approaches (Mead, 1934, Erikson 1959) tackled identity as a concept referring to the continuity and stability of social structures, and emphasised fixed social role models as tools that help individuals to construct their identity. Such models have thus revolved around the professions, social roles, functioning and inherited a positions in public and private spheres (cf. Kellner, 1995). Alongside the growing awareness that globalisation, transnational economic, political and social flows, and the expansion of mass media have changed the world, more discursive approaches and the meaning of self-representations have undermined the ideas that social location determines one's subjective identity (Bottero, 2010). It has become more appropriate to talk about identification as a process of constant (self)-recognition rather than about an identity as a static "property of the individual" (Hall and Du Gay, 2000:16). Due to new technologies and accelerating movements, new identities of mobile, free and unattached individuals have come to the fore. Being exposed to mass media and the same cultural element enables components from the most disparate and remote discourses without any spatial or temporal continuity to be placed together, and thus contributes to the construction of identities (Bagnoli, 2007:24). However, having too many cultural resources at one's disposal can present an obstacle in terms of exaggerated confusion and dispersion in the individual's interpretation of self. Accordingly, identities have become more fluid and reflexively constructed in order to recognise that the only factor that enables continuity in the individual's biography and personal narratives is the ability to make cultural choices (Delanty, 2000:160).

The idea of reflexivity, as discussed herein, stems from interpretations of social changes and transformations linked to the expansive changes in communication technologies and structures. Reflexivity has become an important concept in the social theory mostly associated with Beck, Giddens and Lash, but it has offered an intellectual framework for the interpretation of modernity to a wider range of theorists from Habermas to various postmodernists such as Lyotard, Bauman and Touraine and Melucci (Delanty, 2000). Reflexivity is associated with individualism and individualisation and refers to the relationship between subjectivity - Oneself - and objectivity - Other. It is a means of mediation which links subjective and objective 
domains (Delanty, 2000). Reflexivity as a category of mediation has been systematically explored by Giddens in his structuration theory (1984) which emphasises the duality and dialectical interplay of agency and structure, and sees structural properties as both the medium and outcome of practices. People engage in practices and it is through those practices that both consciousness and structure are produced. It has been argued that in late modern societies reflexivity also plays a major role in self-identity. Giddens attributes individuals with an ability to make a difference in the social world as their everyday activities seem to have a global impact. By monitoring the ongoing flow of activities and structural conditions, the individual lives a reflexively organised biography. Institutional positions determining individuals have started to present not just events and conditions influencing their lives, but at least the consequences of the decisions that they make on their own (Beck, 1992:199).

According to theories of individualisation, it is not actually a matter of choice but the individual is in a way forced to become the agent of their own identity making and livelihood (Beck and Beck - Gernsheim, 2002). However, it has been argued that those perspectives view reflexivity more as the ability of self-monitoring and neglect personal creativity and imagination (Mutch, 2007). In exploring identifications, attention should also be paid to ideas of the individual's uniqueness and the ability to identify oneself and others within the unique world of thoughts, feelings and performances. The conceptualisations of Margaret Archer, who postulates the meaning of 'internal conversation', seem to bring us a little further in our discussion. In that light, reflexivity is a key mechanism for social changes, taking shape through the relationship between individual and structure, but always in the domain of individuals (Archer, 2003). Individuals reflexively influence their actions and by so doing they simultaneously influence the social structure. In that sense, reflexivity is a mediator between structure and agency. Agents deliberate upon social circumstances they confront via internal conversation. Having a personal identity, as defined by their individual configuration of concerns, they are able to decide what they care about most and what they seek to realise in society (Archer, 2003; Mutch, 2007). These internal conversations have proved to be radically heterogeneous and shaped by the interplay of the social situation and the personal concerns of agents. As part of this formation, differential access to resources (cognitive and physical) is crucial (Archer 2003; Mutch 2007).

At this point, the ideas of Appadurai's (1996) imagination and aspiration are also relevant since, due to pervasive electronic mediation, mass mediation and mass migration, they have become a collective, social act. People have begun to deploy their imagination in the practice of their everyday life, and this represents a basis for attaching meaning to the world around them. However, imagination and aspirations are formed in the "thick of social life", and are not evenly distributed in society (Appadurai, 2004), which calls the assumed liberation from social structures into question.

The conditions allowing transnational identities to emerge and the processes of imagination and construction which enable and embody the existence of such identities through social practices are issues that concern us the most. Recent research 
confirms that people can have multiple identities but that these identities are not always equally present. It is not something people 'have' or 'are' all of the time (Risse, 2004). The globalised social reality, which at the same time is also highly fragmented, provides the basis for ambiguous and multi-layered identities referring to local or national traditions and allegiances intertwined with global cultural patterns. If we see identities as a result of the dialogical model between the self and the other, the pole of the other can be broadly understood as a multiplicity of voices arising from both within and without the subject. Considering the new social context signified by global connections and new uncertainties of individualisation, we may increasingly be able to define hybrid identities, adding new dimensions of significance to ourselves. However, this is not an uncontested, linear process. The question remains whether hybridity can only be in the domain of privileged social groups (Bagnoli, 2007:25). One's position in the social setting therefore still plays an important role.

Perspectives which emphasise continuity of established social differences as the basis for identities lean on Bourdieu's idea of habitus. In that sense, individuals act in the context of a structured framework of evaluations and expectations which lead to the conscious or intuitive prioritising of certain dispositions and practices. This framework is what he calls a habitus. A habitus provides the context in which various forms of capital are valued and gain meaning. It is defined as a system of dispositions (lasting, acquired schemes of perception, thought and action). Agents develop these dispositions in response to the objective conditions they encounter. A habitus enacts the structures of the field, and the field mediates between the habitus and practice (Bourdieu, 1990:23-25). The possibilities of agency and the (re)negotiation of power relations are thus ever present. Nevertheless, as Adams emphasises, agency and autonomy are qualified by the caveat of accumulated history, both personal and collective, which imprint themselves as pre-reflective action-orientations (Adams, 2006). Accordingly, Bourdieu's approach is often criticised for emphasising the continuity of established social differences as the basis for identities. He recognised the role of reflexivity, but that it is as much as the habitual outcome of field requirements as any other disposition (Adams, 2006:515). If identity is seen as the outcome of the dispositional practice, it is "beyond the grasp of consciousness, and hence cannot be touched by voluntary, deliberate transformation, cannot even be made explicit" (Bourdieu, 1977:94).

In focusing on the dispositional nature of identity, also more explicitly reflexive and self-consciously mobilised aspects have been acknowledged, and questions of how to theorise the relation between the reflexive, dispositional and mobilised aspects of identity have risen (Adams, 2006; Bottero, 2010). The paper intends to consider perspectives which seek to combine a dialectic relation between reflexivity and habitus, but in the context of the transnational social sphere. What is important here is not just reflexive choices, which are more present in the transnational sphere, but also what Adams (2006:525) calls a "post-reflexive choice" referring to the ability to convert 'reflexions' into meaningful realities, which always requires particular material, cultural or social resources. 


\section{Transnational social fields}

The use of social fields as an analytical framework for the contemporary identification process allows for the incorporation of recent sociological dominant tropes concerned with identity issues clustered around both self-reflexivity and habitus (cf. Adams, 2006). The concept of social field has been recognised as holding the potential to efficiently confront the issue of agency and structure and it has also informed many empirical findings (Fligstein, 2001). It has been increasingly employed in scholarly attempts concerned with a variety of social phenomena ranging from cultural studies (McNay, 1999; Schirato and Webb, 2003; Adams, 2006; Postill, 2008; Bottero, 2010) to studies of political (Turner, 1974; Laumann and Knoke, 1987; Tarrow, 1998; de Nooy, 2003) and economic influences on collective action and institutional change (White, 1994; Hannan and Freeman, 1984; Hamilton and Biggart, 1988; Fligstein, 1996; Fløysand and Jakobsen, 2002; Beckert, 2010).

The main advantage of the theoretical concept can be seen in how it accords with everyday usage and its attention to the concrete, even though its definition might be quite tautological (Martin, 2003). It is not just its heuristic potential in considering agency-structure that seems to be of great importance. It also refers to micro-macro phenomena in the social reality and thus enables a more integrative perspective on social processes and social change. The unit of analysis can thus be simultaneously composed of social networks and other social forces and individuals or collective agents (Fligstein, 2001; Fløysand and Jakobsen, 2007; Beckert, 2010). It is also a useful concept for exploring identifications in a social world where social, economic and cultural connectivity has increased, and the nature of individual consciousness, people's motivation to pursue their ends and the extent of their freedom from external influences have become a challenging theoretical and empirical task. In order to examine the complex processes of identification in a world where "it sometimes seems as if all the world is on the move" (Urry, 2007:3), we deploy a concept of transnational social fields.

It offers elements of the simultaneity of locality and multiplicity of identities, and can elucidate the situation of many social groups. Transnational social fields seem to enable us to consider the complex process of perceiving the self and others in this world of movement and help us to understand the contested contemporary identifications. We believe the concept of social field and particularly the transnational social field can shed light on certain aspects of the relationship between the individual, society and identification, while it challenges methodological nationalism but still takes account of the social forces and institutions that greatly influence the individual's "biography" (Giddens, 1991).

The concept of transnational social field emerged from migration studies (Fouron and Glick Schiller, 2001; Levitt and Glick Schiller, 2004) focusing on how global processes and flows influence transnational processes, highlight issues of agency and community, facilitate the creation of new transnational social networks, and address issues of identity (Moallem, 2000; Adler, 2000; Tsuda, 2001; Riccio, 2001; Cohen, 2004; Kelly and Lusis, 2006, Gargano, 2009). The concept's roots can be traced to 
the Manchester School of Anthropology where the idea of a field was emphasised in order to explore urbanised localities in conditions of rapid social and political change. Those ideas were elaborated in the seminal work of Nina Glick-Schiller, Linda Basch and Cristina Blanc-Szanton (1994) who defined social fields as a set of multiple interlocking networks of social relationships through which ideas, practices and resources are unequally exchanged, organised and transformed.

The notion called into question over-generalised conceptualisations insinuating a singular set of relations within a field (e.g. Vertovec, 2001). The individuals participating in transnational social spaces or fields are in no way a homogenous group and, accordingly, it has been emphasised that there are many ways of "being transnational", which refers to different social spaces (Smith, 2002). Individuals move through different social fields (Kearney, 1995) which represent a complex set of factors influencing individual practices, attitudes and identifications. The complexity of the internal dynamics of a particular field and the co-influence of a variety of social fields evoked the concepts of "power-geometry" (Massey, 1991, Sørensen, 1998, Vertovec, 2001) or the new cross-border geography (Sassen, 2002) which emphasise the issue of differential embeddedness. The role of social positioning and power relations has been taken into account in the conceptualisation of transnational social fields offered by Levitt and Glick Schiller (2004) who partly built on Bourdieu's ideas of the field. They proposed the concept of social field that differentiates ways of being as opposed to ways of belonging. The former refers to actual social relations and practices that individuals engage in rather than identities associated with their action. In contrast, ways of belonging refer to practices that signal or enact an identity which demonstrates a conscious connection to a particular group. Individuals within transnational social fields can combine both ways differently in a specific context (Levitt and Glick Schiller, 2004:10-11). Our paper is inspired by works (e.g. Glick Schiller and Fouron, 1999; Levitt and Glick Schiller, 2004) emphasising that national boundaries are not necessarily contiguous with the boundaries of social fields, and that transnational social fields connect actors through direct and indirect relations across borders. Transnational social fields comprise various locations that extend across the borders of two or more nation-states and incorporate their participants in the day-to-day activities of social reproduction (Fouron and Glick Schiller, 2001:544). Those conceptualisations of transnational social fields do not differ much from that proposed by Fligstein who sees fields as local social orders or social arenas where "actors gather and frame their actions vis-à-vis one another" (Fligstein, 2001:108). As Levitt and Glick-Schiller argue, "in one sense, all (social fields) are local in that near and distant connections penetrate the daily lives of individuals lived within a locale" (Glick-Schiller, 2004:10). But, as they continue, the concept calls into question divisions of connection into local, national, transnational and global, while within this locale a person may participate in personal networks or receive ideas and information that connect them to others in a nation-state, across the borders of a nation-state, or globally (Glick-Schiller, 2004:10).

Incorporating transnational social field ideas into an analytical approach provides a space for exploring identifications which emerge as a result of individual experiences within different national communities or groups, institutional rules and trans- 
national connections. The subjective self-position and definition is conditioned by the interplay of different social forces, which consist of cognitive frames structuring the perceptions of agents, relational topographies of networks and institutional rules prevalent in the field (e.g. Beckert, 2010).

Individuals or social groups who participate in transnational social fields legally belong to a particular nation-state(s) and are thus embedded in legal and political institutions. It is important to pay attention to the regulation of economic interactions and political processes imposed by nation-states as they influence social action. Further, they interact on the transnational level, which embraces cultural sediments that can pose contested meanings, and they communicate through networks which are widespread. The consideration of the role of all three dimensions of individuals' positioning and acting within a field offers a more comprehensive view on identity construction in the transnational sphere. Local order (cf. Fligstein, 2001) in which individuals take their actions and simultaneously produce meanings with regard to each other's behaviour emerges through a set of social forces. The focus is on the idea that different aspects of identity can be related to the features of situated intersubjectivity, while intersubjective practice is experienced not just in terms of dispositions to act but also as a relation to the expectations and influence of the concrete networks of others (Bottero, 2010:16).

Participation in transnational social fields is influenced by participation in other (national) social fields that disposes an individual to a lifestyle or way of living associated with the particular social group from which they derive. An important issue here therefore refers to the different backgrounds of the individual, which reflects the influence of all three mentioned social forces and the role of different types of capital, which is always field-specific and contingent upon others recognising its value (Bourdieu and Wacquant, 1992). Individuals incorporate their own histories referring to a particular local and national environment into the transnational sphere, where they bounce into each other. They come into contact with a variety of social memories, narratives and values which influence the process of meaningmaking and consequently identity constructions. But the latter does not mean that during this process a simple version of identity-bricolage emerges. The process is conditioned by an intersubjective consideration whereby individuals share their perceptions and beliefs and reframe their accounts of their practice and meaningmaking. The cognitive frames gain the transnational component which is sustained and reproduced through the circulation of culture capital in its transnational form. The context in which various forms of capital are valued and gain a meaning was called a habitus (Bourdieu, 1977). The existence of different types of capital, be it cultural, social or economic, which take on a transnational form provides the space for elaborating the issue of transnational habitus.

Drawing upon Bourdieu, Luis Guarnizo (1998) proposed the idea of habitus in a transnational form whereby practices and social positions that spread across borders produce conscious and non-conscious dispositions to act in specific ways in specific situations. A transnational habitus is constituted by dispositions emerging from different local and national environments, and reflects a different context of a struc- 
tured framework of evaluations and expectations which, as proposed by Bourdieu, lead to the conscious or intuitive prioritising of certain dispositions and practices (e.g. Kelly and Lusis, 2006). Habitus referring to transnational social fields implies a different meaning to that originally asserted as it is more defined by movement between places, which allows more reflexive considerations of an individual's action within structured positions.

Utilising transnational habitus in a conceptual framework of transnational identifications raises the issue of the relationship between reflexivity and structured positions. Discussions which have sought to combine both perspectives focus on the possibility of shifting between unevenly aligned, relatively autonomous fields to enable reflexivity (McNay, 1999). The lack of fit between fields is always possible and this lack is the space in which reflexivity can emerge, particularly during a time of crisis (Bourdieu and Wacquant, 1992:131). It has been argued that contemporary society is much more routinely marked by crises emanating from movements between fields, enabling reflexivity to emerge from a specific and concrete negotiation of conflictive fields (Adams, 2006:51).

If we presuppose that practice is anchored intersubjectively, the experience not only embraces dispositional actions but also the relation to expectations, aspirations, imagination and an influence on concrete networks. The potential indeterminacy between dispositions and collective practice creates a space for ambivalence in relation to the constraints of collective practice not simply in terms of the dissonance between habitus and field, but as a general feature of practice (cf. Bottero, 2010). The interdependence, mutual influence and accountability which constrain individual actions also enable joint practice, collective pursuits and group mobilisation. In the case of transnational social fields, movement between different social fields is a daily process.

As mentioned, in order to enter transnational social fields one needs to participate in other national and local fields. Transnational social fields express participation in social worlds that stretch between more than one country through various transnational channels and networks. Individuals have to negotiate their presence on different levels which are socially and geographically distant. Their transnational way of being or belonging reflects a certain extent of ambivalence, which demands from every individual a particular consideration of their actions. Only then are they able to give a proper meaning to their existence, attachments and belongings, and place themselves in a social context. They also possess a great amount of social capital which takes on a transnational form and makes intersubjective meaning-making even more specific. Constant reflexivity is thus an inevitable fact.

The possibility of reflexivity is also conditioned by other social contexts. As Beckert (2010:606) argues, structure places actors within a field in more or less powerful positions who gain resources from their position and become able to influence social forces (institutions, network structures, and cognitive frames). Reflexivity, which allows a subjective consideration of someone's action, is also a result of embeddedness in a differentiated resource context. Or, as we have already emphasised in the 
paper, agents' consideration of the social circumstances they confront via internal conversation is also influenced by their differential access to resources (cognitive and physical) (Archer, 2003). The possession of different types of capital is crucial in self-positioning and defining a self, which contributes to self-identifications. Lash and Urry, for instance, offered the perspective of reflexivity winners and losers in order to specify the extent to which structural conditions influence reflexive agency (Lash and Urry, 1994:6). We argue that, in this sense, participants in transnational social fields are all winners (in a different extent) as they have available a great amount of different sorts of capital which they can use in order to achieve their goals. Through transnational networks, the individual can distribute not only economic but also symbolic and cultural resources that rely on the resources of two or more countries. There is also an important role of social capital transferring through transnational networks which raises the possibility of reflexivity. It has been argued that in the contemporary era communication represents the cultural mechanism enabling the mediation of reality and options of agency.

Therefore, to make a meaningful choice, whether individual or collective, access to information and communication is crucial (Delanty, 2000). Individuals within transnational social fields are better equipped to influence social forces. For instance, the influence on institutional rules is well evident in the case of transnational migrants, who can hold dual citizenship and vote, lobby or finance campaigns in more than one system and can accordingly exert an influence beyond the domain of direct political action, and in the distinction between legal citizens and non-citizens (see Glick-Schiller, 2005). They can influence legal and social status and economic and political relations in both locations. Not just migrants but also other transnational actors are able to establish and sustain broad social networks that extend beyond different boundaries and are thus more capable of guiding their actions. Also their cognitive frame allows for greater flexibility and adaptation to the social context.

The transnational way of being is not automatically linked to a conscious connection to a certain group and belonging but, as Levitt and Glick Schiller (2004) hypothesise, someone with access to a transnational way of belonging is likely to act on that at some point in their life. Social fields comprise institutions, organisations and experiences that generate categories of identities that are ascribed to or chosen by individuals or groups. A transnational layer of identities can be a consequence but also a deliberate decision. For instance, in the case of transnational migrants it has been shown that individuals can consciously choose and switch between multiple identities (Golob, 2009). The success of migrants involved in transnational activities does not depend so much on abandoning their culture and language to embrace those of another society as on preserving their original cultural endowment, while adapting instrumentally to a second one (Portes et al., 1999). Identifications could take on an instrumental value and accordingly play a significant role in an individual's agency in transnational processes. A border crossing, whether physical or cognitive, constantly demands a transformation and redefinition of someone's identity, while multi-layered and changeable identifications represent an essential and effective strategy for individuals (Repič, 2010). 
According to the growth of global communications, media, consumerism and popular culture, individuals negotiate traditions, memories, and feelings of belonging in never-ending struggles to form and re-form new ambivalent identities. Transnational connections offer important insights into social actions and meaning-making as they acknowledge individuals' degree of agency in deciding how they may identify and act, while depending on the context with which they are engaged. Transnational social fields are in a way sites of resistance whereas multi-layered identifications and transnational practices represent a conscious effort to escape control of capital and the state (Guarnizo, 1998; Low and Zúñiga, 2003) although they cannot fully escape their influence. Transnational social capital plays a crucial role in this regard. In order to address an interactive dimension of social games allowing for a consideration of more reflexive dimensions of habitus (Mouzelis, 2007), it seems important to focus on existing social networks individuals use to organise their life. Individuals share their perceptions and beliefs and continually provide "accountability" to each other as a basis of coordinating understandings and practice.

Intersubjective practice, which is based on an inter-subjective habitus (Bottero, 2010), seems to be close to the idea of a social skill proposed by Fligstein (2001). It means that actors have to motivate others to cooperate and express the ability to engage others in collective action. A social skill proves pivotal to the construction and reproduction of local social orders. It bears a resemblance to the ideas of Anthony Giddens regarding the "skilled reproduction of social skill" (1984) and Hans Joas' notion of the "creativity of social action" (1996) referring to the idea that skilled strategic actors provide identities and cultural frames to motivate others. Accordingly, there is a great difference between individuals' processes of identification within a particular social field to which one should pay attention. Transnational individuals or groups are those who maintain connections, build institutions, conduct transactions and influence local and national events at multiple sites. But the extent of their success in those terms depends on the possession of various forms of capital and social skills which also influence their negotiation of identities, which reversely offers a source for their strategising in gaining power to control their life. There is more than one way to be a transnational actor and the concept of transnational social fields allows a closer examination of different historical backgrounds, social, political and cultural contexts, and social interactions in individuals' sense-making.

\section{Concluding remarks}

Individuals in the modern world participate in many social fields which do not always correlate with local or national boundaries. Global processes enable the existence of transnational social fields which forces us to re-examine and reconceptualise the relationship between social spaces, physical locales, and the geography of the mind. Use of the concept does not predict or limit how spaces, identities, or networks of association are created or negotiated, but recognises various power dynamics and outcomes that manifest when individuals from different social and cultural environments encounter each other (Gargano, 2009:334-335). 
The use of transnational social fields in a conceptual framework to explore identifications allows a closer examination of the complex interaction between individual practices and transnational, national and local contexts. In that sense, it is important to take account of the cultural, social and political horizons influencing the variety of pre-existing dispositions in people's reality. They condition and substitute the dispositional set of habitus and influence transnational identifications. Further, we have to take into account the dialectic relationship between the reflexive, collective and dispositional components of the identification processes. In efforts to explore identifications within the transnational sphere, one needs to consider "the intersubjective nature of practice, and the concrete 'calls to order' that arise from networks of variously disposed agents, whose actions must be accounted for, negotiated and aligned" (Bottero, 2010:20). The concept allows us to investigate how socio-economic, cultural and personal backgrounds influence someone's identity negotiations and constructions in the transnational sphere, while it also encompasses the influence of border crossing and transnational connections. It takes account of the role of the positionality of individuals, individual experiences and reflexive considerations of someone's actions, institutional rules and relevant aspects of international communities and groups. Therefore, it embraces the simultaneity of locality and multiplicity in identifications, while its theoretical implications offer a springboard for empirical research.

\section{Bibliography}

1. Adams, M. (2006). Hybridizing Habitus and Reflexivity: Towards an Understanding of Contemporary Identity?. Sociology, 40 (3): 511-528.

2. Adler, A. (2000). Human agency in international migration: The maintenance of transnational social fields by Yucatecan migrants in southwestern city. Mexican Studies, 16: 165-187.

3. Appadurai, A. (1996). Modernity at Large: Cultural Dimensions of Globalization. Minneapolis: University of Minnesota Press.

4. Appadurai, A. (2004). The Capacity to Aspire: Culture and the Terms of Recognition, in: Vijayendra R. and M. Walton (eds). Culture and Public Action. Stanford University Press: 3-29.

5. Archer, M. (2003). Structure, Agency, and the Internal Conversation. Cambridge, New York: Cambridge University Press.

6. Bagnoli, A. (2007). Between outcast and outsider: constructing the identity of the foreigner. European Societies, 9 (1): 23-44.

7. Basch, L.; N. G. Schiller and C. Blanc-Szanton (eds.) (1994). Nations Unbound: Transnational Projects, Postcolonial Predicaments, and Deterritorialized Nation-states. Langhorn: Gordon and Breach.

8. Bauman, Z. (2000). Liquid Modernity. Cambridge: Polity.

9. Beck, U. (1992). Risk Society. Towards a New Modernity. London: Sage.

10. Beck, U. and E. Beck-Gernsheim (2002). Individualisation. London: Sage.

11. Beck, U.; A. Giddens and S. Lash (1994). Reflexive Modernization. Politics, Tradition and Aesthetics in the Modern Social Order. Stanford University Press 
12. Beckert, J. (2010). 'How Do Fields Change? The Interrelations of Institutions, Networks, and Cognition in the Dynamics of Markets'. Organization Studies, 31 (5): 605-627.

13. Bottero, W. (2010). Intersubjectivity and Bourdieusian approaches to 'identity'. Cultural Sociology, 4: 3-22.

14. Bourdieu, P. (1977). Outline of a Theory of Practice. Cambridge. Cambridge University Press.

15. Bourdieu, P. (1990). The Logic of Practice. Stanford, CA, Stanford University Press.

16. Bourdieu, P. and L. Wacquant (1992). An Invitation to Reflexive Sociology. Cambridge: Polity Press.

17. Brubaker, R. and Cooper, F. (2000). Beyond "Identity". Theory and Society, 29: $1-47$.

18. Castells, M. (1997). The Power of Identity. Oxford: Blackwell.

19. Cohen, E. (2004). I am my own culture: The "individual migrant" and the "migrant community", a Latin American case study in Australia. Journal of Intercultural Studies, 25 (2): 123-142.

20. Delanty, G. (2000). Modernity and postmodernity: Knowledge, power and the self. London; Thousand Oaks; New Delhi: Sage.

21. De Nooy, W. (2003). Fields and networks: Correspondence analysis and social network analysis in the framework of Field Theory. Poetics, 31: 305-27.

22. Erikson, E. H. (1959). Identity and the life cycle: Selected papers. Psychological Issues, 1: 1-171.

23. Fligstein, N. (1996). Markets as Politics: A Political-Cultural Approach to Market Institutions. American Sociological Review, 61: 656-73.

24. Fligstein, N. (2001). Social Skill and the Theory of Fields. Sociological Theory, 19: $105-125$

25. Fligstein N. and D. McAdam (2012). A Theory of Fields. Oxford: Oxford University Press.

26. Fløysand, A. and S.-E. Jakobsen (2002). Clusters, social fields and capabilities: Rules and restructuring in Norwegian fish processing clusters. International Studies of Management and Organisation, 31: 36-57.

27. Fouron, G. E. and N. G. Schiller (2001). The generation of identity: Redefining the second generation within a transnational social field, in: H. R. CorderoGuzman and R. C. Smith (Eds.). Migration, transnationalization and race in changing New York. Philadelphia: Temple University Press, 292-403.

28. Gargano, T. (2009). (Re)conceptualizing International Student Mobility: The Potential of Transnational Social Fields. Journal of Studies in International Education, 13 (3): 331-346.

29. Gergen, K. J. (1991). The Saturated Self: Dilemmas of identity in contemporary life. New York: Basic Books.

30. Giddens, A. (1984). The Constitution of Society. Cambridge: Polity Press.

31. Giddens, A. (1991). Modernity and Self-Identity. Cambridge: Polity.

32. Glick Schiller, N. (2005). Transborder Citizenship: An Outcome of Legal Pluralism within Transnational Social Fields, in: Franz Bender Beckman and Keebit Bender Beckman (eds). Mobile People, Mobile Law: Expanding Legal Relations in a Contracting World. London: Ashgate, 27-51.

33. Golob T. (2009). Slovenian migrants in transnational social spaces: Exploring multilayered identifications and ambivalent belongings. Anthropological Notebooks, 15 (3): 65-77. 
34. Guarnizo, L. E. (1998). The Rise of Transnational Social Formations: Mexican and Dominican State Responses to Transnational Migration. Political and Social Theory, 12: 45-94.

35. Hall, S. and P. Du Gay (2000). Questions of Cultural Identity. London: Thousand Oaks, New Delhi: Sage.

36. Hamilton. G. and N. Biggart (1988). Market Culture and Authority. American Journal of Sociology, 94: 52-94.

37. Hannan, M. and J. Freeman (1984). Structural Inertia and Organizational Change. American Sociological Review, 49: 149-64.

38. Harvey, D. (1989). The Condition of Postmodernity. Oxford: Blackwell.

39. Held, D. and A. McGrew (2002). Governing Globalization. Cambridge: Polity Press.

40. Jacobs D. and R. Maier (1998). European identity: Construct, fact and fiction, in: Gastelaars, M. and de Ruijter, A. (eds.). A United Europe. The Quest for a Multifaceted Identity. Maastricht: Shake.

41. Joas, H. (1996). The Creativity of Action. Chicago, IL: University of Chicago Press.

42. Kearney, M. (1995). The Local and the Global: The Anthropology of Globalization and Transnationalism. Annual Review of Anthropology, 24: 547-65.

43. Kelly, P. and T. Lusis (2006). Migration and the Transnational Habitus: Evidence from Canada and Philippines. Environment and Planning, 38: 831-847.

44. Kellner, D. (1995). Media Culture: Cultural Studies, Identity and Politics Between the Modern and the Postmodern. London: Routledge.

45. Lash S. and J. Urry (1994). Economies of Signs and Space. London: TCS.

46. Laumann, E. and D. Knoke (1987). The Organizational State. Madison, WI: University of Wisconsin Press.

47. Levitt, P. and N. Glick Schiller (2004). Conceptualizing simultaneity: Transnational social field perspective. International Migration Review, 38 (145): 595629.

48. Low, S. M. and D. Lawrence-Zúñiga (eds.) (2003). The Anthropology of Space and Place: Locating Culture. Malden, Oxford, Carlton and Berlin: Blackwell Publishing.

49. Martin J. (2003). What is Field Theory?. American Journal of Sociology, 109: $1-49$.

50. McNay, L. (1999). Gender, Habitus and the Field: Pierre Bourdieu and the Limits of Reflexivity. Theory, Culture and Society, 16 (1): 95-117.

51. Mead, G. H. (1934). Mind, Self, and Society. Chicago, IL: University of Chicago Press.

52. Moallem, M. (2000). "Foreignness" and be/longing: Transnationalism and immigrant entrepreneurial experiences. Comparative Studies of South Asia, Africa and Middle East, XX: 200-216.

53. Mouzelis N. (2007). Habitus and Reflexivity: Restructuring Bourdieu's Theory of Practice. Sociological Research Online, 12 (6): 9.

54. Mutch, A. (2007). Making connections: Agency, reflexivity and structure. Paper for the 'Making Connections'workshop, Cardiff Business School 2-3 April, 2007.

55. Portes, A.; L. E. Guarnizo, and P. Landolt (1999). The Study of Transnationalism: Pitfalls and Promise of an Emergent Research Field. Ethnic and Racial Studies, 22 (2): 217-237. 
56. Rapport, N. and A. Dawson (eds.) (1998). Migrants of Identity: Perception of Home in the World of Movement. Oxford and New York: Berg.

57. Repič J. (2010). Ambivalent identities emerging in transnational migrations between Argentina and Slovenia. Dve domovini, 31: 121-134.

58. Riccio, B. (2001). From "ethnic group" to "transnational community"? Senegalese migrants' ambivalent experiences and multiple trajectories. Journal of Ethnic and Migration Studies, 27: 583-599.

59. Risse, T. (2004). European Institutions and Identity Change: What Have We Learned?, in: R. Herrmann, T. Risse and M. Brewer (eds). Transnational identities. Becoming European in the EU. Lanham: Rowman \& Littlefield Publishers.

60. Rončević, B. and M. Makarovič (2012). Societal steering in theoretical perspective: Social becoming as an analytical solution. Polish Sociological Review, 176 (4): 461-472.

61. Sassen, S. (2000). New frontiers facing urban sociology at the Millennium. British Journal of Sociology, 15 (1): 143-59

62. Schirato T. and J. Webb (2003). Understanding Globalization. Sage: London and New Dehli.

63. Smith, M. P. (2002). Preface, in New Approaches to Migration?. N. Al-Ali and K. Koser (eds). London: Routledge.

64. Tarrow S. (1998). Power in Movement: Social Movements and Contentious Politics. Cambridge University Press.

65. Tsuda, T. (2002). From ethnic affinity to alienation in the global ecumene: The encounter between Japanese and Japanese-Brazilian return migrants. Diaspora, 10 (1): 53-91.

66. Turner, V. W. (1974). Dramas, Fields and Metaphors: Symbolic Action in Human Society. Ithaca, NY: Cornell University Press.

67. Urry, J. (2003). The Global Complexity. Cambridge: Polity Press.

68. Urry, J. (2007). Mobilities. Cambridge and Malden: Polity Press.

69. Vertovec S. (2001). Transnationalism and identity. Journal of Ethnic and Migration Studies, 27: 573-582.

70. White, H. (1994). Identity and Control. Princeton, NJ: Princeton University Press. 
Pregledni rad

Te a Golob

Fakulteta za uporabne družbene študije, Nova Gorica, Slovenija

e-mail: tea.golob@fuds.si

\section{Istraživanje identifikacijskih procesa u transnacionalnoj društvenoj sredini: potencijal društvenih polja}

\section{Sažetak}

Članak se bavi pitanjima suvremenih identifikacijskih procesa, društvenih promjena i tehnološkog razvoja koji se odražavaju u transnacionalnoj društvenoj sredini. Prvo je pitanje mogućnosti individualnog djelovanja unutar društvene zadanosti i prostor individualne slobode bez vanjskog utjecaja je u prvom planu. Drugi je predmet interesa individualna ili kolektivna percepcija sebe i vanjskog svijeta što se onda nadovezuje na sljedeće pitanje: kako zapravo promišljati gradnju identiteta ili identifikaciju u transnacionalnim društvenim sredinama? Vjerujemo da pojam društeno polje, osobito transnacionalno društveno polje, može rasvijetliti složeni odnos pojedinca i društva te ukazati na važne aspekte formiranja identiteta. U današnje moderno doba, pojedinci djeluju na mnogo društvenih polja koja se nužno ne podudaraju s lokalnim ili nacionalnim granicama. Stoga je mogućnost za njihovu individualnu slobodu i društvenu promjenu veća ali ipak uvjetovana raznim vrstama kapitala i drugih društvenih snaga. To priziva ideju habitusa koji odražava drukčiji okvir vrijednosti i očekivanja koji onda, kako kaže Bourdieu (1977.), vodi prema svjesnom ili intuitivnom davanju prednosti nekim dispozicijama i praksama. Koncept društvenog polja nam omogućuje da istražimo kako socioekonomski, kulturni i osobni background utječu na oblikovanje i gradnju identiteta u transnacionalnoj sredini te istovremeno obuhvaća utjecaj prelaska granice i transnacionalnih veza.

Ključne riječi: identifikacijski proces, društvena polja, transnacionalne veze. 